\title{
Low dosage of arsenic trioxide inhibits vasculogenic mimicry in hepatoblastoma without cell apoptosis
}

\author{
FENG ZHANG ${ }^{1}$, CHUN-MEI ZHANG $^{1}$, SHU LI $^{2}$, KUN-KUN WANG $^{1}$, BIN-BIN GUO ${ }^{1}$, \\ YAO FU ${ }^{1}$, LU-YANG LIU ${ }^{1}$, YU ZHANG ${ }^{1}$, HAI-YU JIANG ${ }^{1}$ and CHANG-JUN WU ${ }^{1}$ \\ Departments of ${ }^{1}$ Ultrasonography and ${ }^{2}$ Cardiovascular, The First Affiliated Hospital of \\ Harbin Medical University, Harbin, Heilongjiang 150001, P.R. China
}

Received February 9, 2017; Accepted October 12, 2017

DOI: $10.3892 / \mathrm{mmr} .2017 .8046$

\begin{abstract}
Hepatoblastoma (HB) is the most common type of pediatric liver malignancy, which predominantly occurs in young children (aged $<5$ years), and continues to be a therapeutic challenge in terms of metastasis and drug resistance. As a new pattern of tumor blood supply, vasculogenic mimicry (VM) is a channel structure lined by tumor cells rather than endothelial cells, which contribute to angiogenesis. VM occurs in a variety of solid tumor types, including liver cancer, such as hepatocellular carcinoma. The aim of the present study was to elucidate the effect of arsenic trioxide $\left(\mathrm{As}_{2} \mathrm{O}_{3}\right)$ on VM. In vitro experiments identified that HB cell line HepG2 cells form typical VM structures on Matrigel, and the structures were markedly damaged by $\mathrm{As}_{2} \mathrm{O}_{3}$ at a low concentration before the cell viability significantly decreased. The western blot results indicated that $\mathrm{As}_{2} \mathrm{O}_{3}$ downregulated the expression level of $\mathrm{VM}$-associated proteins prior to the appearance of apoptotic proteins. In vivo, VM has been observed in xenografts of $\mathrm{HB}$ mouse models and identified by periodic acid-Schiff $/$ CD105 channels lined by HepG2 cells without necrotic cells. $\mathrm{As}_{2} \mathrm{O}_{3}$ $(2 \mathrm{mg} / \mathrm{kg}$ ) markedly depresses tumor growth without causing serious adverse reactions by decreasing the number of VM channels via inhibiting the expression level of VM-associated proteins. Thus, the present data strongly indicate that low dosage $\mathrm{As}_{2} \mathrm{O}_{3}$ reduces the formation of $\mathrm{VM}$ in $\mathrm{HB}$ cell line HepG2 cells, independent of cell apoptosis in vivo and in vitro, and may represent as a candidate drug for HB targeting VM.
\end{abstract}

Correspondence to: Dr Chang-Jun Wu, Department of Ultrasonography, The First Affiliated Hospital of Harbin Medical University, 23 Youzheng Street, Harbin, Heilongjiang 150001, P.R. China

E-mail: doctor_zf@163.com

Key words: hepatoblastoma, arsenic trioxide, vasculogenic mimicry, vascular endothelial-cadherin, matrix metalloproteinase

\section{Introduction}

Hepatoblastoma (HB) is a common type of liver malignancy in young children, which is typically diagnosed in those $<5$ years (1). HB accounts for $>90 \%$ of malignant liver tumors in childhood (2). The incidence of HB is $>1.2$ million children every year globally, with high incidences in Japan, China and USA (3). The etiology of HB remains unclear, and low birth weight, preterm birth and maternal gestational age $(<20$ years and $>35$ years) may be associated with the morbidity of HB $(1,4)$. HB is hypothesized to originate from primitive hepatic stem cells and it is not associated with hepatic virus infection, cirrhosis or other liver disease, which is different from malignant liver tumors in adults. The primary treatment strategies for HB are surgical resection and chemotherapy. However, the prognosis of $\mathrm{HB}$ remains poor, as $\mathrm{HB}$ is a tumor of hypervascularity, the majority of patients are asymptomatic and many cases are diagnosed at a late stage. In addition, the treatment of $\mathrm{HB}$ continues to be challenging due to drug resistance and the occurrence of metastasis, such as lung, brain and lymph gland metastasis $(5,6)$. Thus, there is an urgent requirement to investigate the pathogenesis of HB and develop novel therapeutic targets for the treatment of patients with HB.

Malignant solid tumors must acquire sufficient blood supply to promote their survival, proliferation and metastasis. There are three dominant tumor microcirculation patterns, including angiogenesis, mosaic vessels and vasculogenic mimicry (VM). VM was first reported in melanoma by Maniotis et al (7) in 1999, which described the specific capacity of tumor cells to form extracellular matrix (ECM)-rich networks. It is distinct from angiogenesis and predominantly occurs in the early stage of tumorigenesis (8). VM is lined by tumor cells, which may provide the tumor with oxygen and nutrients, and has been observed in different types of cancer, and is associated with high tumor grade, invasion, metastasis and short survival (9-18). Li et al (12) reported that patients with VM were at a higher risk for hematogenous metastasis and distant recurrence when compared with patients without VM (12). Antiangiogenic drugs have been demonstrated to be unsatisfactory in the treatment of malignant tumors during clinical trials and animal testing over the past decades (19-21). This may be attributed to the particular structure of the VM, which is lined by tumor cells rather than endothelial cells, meanwhile 
the tumor cells engaged in VM are exposed directly to the blood flow and thus more easily spread throughout the circulation. Therefore, VM may be an important target for novel cancer therapeutic strategies to treat tumors.

Arsenic trioxide $\left(\mathrm{As}_{2} \mathrm{O}_{3}\right)$ has been used to successfully treat acute promyelocytic leukemia $(22,23)$ and other types of cancer cell lines (24-28). $\mathrm{As}_{2} \mathrm{O}_{3}$ induces cell apoptosis, and reduces the invasive and metastatic activities in cancer cells $(24,25,29)$, which involve the caspase-3 signaling pathway, reactive oxygen species, DNA damage, oxidative stress and cell cycle arrest. However, $\mathrm{As}_{2} \mathrm{O}_{3}$, as a vascular disrupting agent, delayed tumor growth in colon cancer and gastric cancer cells at a dose of $>2.5 \mathrm{mg} / \mathrm{kg}$ in a mouse model $(30,31)$. However, the effectiveness of $\mathrm{As}_{2} \mathrm{O}_{3}$ is based upon a high concentration or long exposure and cell toxicity, which leads to undesirable side effects and limits the application of this drug. A previous study reported that $\mathrm{As}_{2} \mathrm{O}_{3}$ exerted its antitumor activity via depletion of regulatory $\mathrm{T}$ cells in a murine model of colon cancer at a low concentration without side effects (32). To the best of our knowledge, whether the rapid progression of $\mathrm{HB}$ is associated with VM formation and whether a low dosage of $\mathrm{As}_{2} \mathrm{O}_{3}$ exerts inhibitory effects on VM formation in $\mathrm{HB}$ have not been reported. The aim of the present study was to investigate the impact of a low dosage of $\mathrm{As}_{2} \mathrm{O}_{3}$ on $\mathrm{VM}$ formation in $\mathrm{HB}$ and the relative mechanisms in order to develop novel therapeutic strategies for $\mathrm{HB}$.

\section{Materials and methods}

Chemicals.The $\mathrm{As}_{2} \mathrm{O}_{3}$ solutionwaspurchasedfromHeilongjiang Harbin Medical Pharmaceutical Co., Ltd. (Heilongjiang, China). Matrigel was purchased from BD Biosciences (Franklin Lakes, NJ, USA), the CD105-antibody was purchased from Thermo Fisher Scientific, Inc. (Waltham, MA, USA), and anti-vascular endothelial (VE)-cadherin, anti-Bcl-2-associated X protein (Bax) and anti-B-cell lymphoma 2 (Bcl-2) antibodies were purchased from Santa Cruz Biotechnology, Inc. (Dallas, TX, USA). Matrix metalloproteinase (MMP)-2 and MMP-9 antibodies were purchased from Nanjing KeyGen Biotech Co., Ltd. (Nanjing, China), and the animals were obtained from Hunan Slack Jingda Experimental Animals Co., Ltd. (Hunan, China).

Cell culture and animal treatment. The HB-derived cell line HepG2 cells were donated by the Department of General Surgery of the First Affiliated Hospital of Harbin Medical University (Harbin, China). Cells were cultured in high-glucose Dulbecco's modified Eagle's medium (DMEM) supplemented with $10 \%$ heat-inactivated fetal bovine serum (both from Gibco; Thermo Fisher Scientific, Inc.) and 1\% penicillin/streptomycin. All cells were maintained at $37^{\circ} \mathrm{C}$ in a humidified incubator with $5.0 \%$ carbon dioxide.

The present study was approved by the Ethics Committee of The First Affiliated Hospital of Harbin Medical University (Heilongjiang, China). A total of 10 healthy male nude mice (age, 4-6 weeks; weight, 18-22 g) were used in the present study. The animals were maintained under specific pathogen-free conditions using a laminar airflow rack. The animals had access to sterilized food and autoclaved water ad libitum, and experiments commenced after 1 week of acclimatization. Mice were injected subcutaneously in the right flank with $1 \times 10^{6} / \mathrm{ml}$ HepG2 cells suspended in $200 \mu 1$ serum-free DMEM, and were randomly allocated into two groups following the injection of tumor cells. Then, $2 \mathrm{ml} \mathrm{As}_{2} \mathrm{O}_{3}(2 \mathrm{mg} / \mathrm{kg})$ or an equivalent volume of phosphate-buffered saline (PBS) was administered intraperitoneally every 2 days for a total of 20 days. Tumor size was measured using Vernier calipers every 2 days, and tumor volume (TV) was calculated using the formula, TV $\left(\mathrm{mm}^{3}\right)=\left(\mathrm{LxW}^{2}\right) / 2$, where $\mathrm{L}$ and $\mathrm{W}$ were the longest and shortest tumor dimensions, respectively. Growth curves of TV were drawn for the two groups. The mice were carefully monitored for symptoms of toxicity and were weighed twice a week. The mean mouse body weight of each group was calculated and used as a parameter of toxicity, as previously described (33). The mice were anesthetized before the tumors were removed, and the tumors were weighed and fixed with $10 \%$ formaldehyde for the pathological tissue sections.

Methylthiazol tetrazolium (MTT) cell viability assay. MTT assay was conducted to assess the effect of $\mathrm{As}_{2} \mathrm{O}_{3}$ on the viability of HepG2 cells. Cells were seeded in 96-well plates at a density of 5,000 cells/well, experiments were performed as follows: Varying concentrations of $\mathrm{As}_{2} \mathrm{O}_{3}$ for $24 \mathrm{~h}$ and $2 \mu \mathrm{M}$ $\mathrm{As}_{2} \mathrm{O}_{3}$ for varying durations. A culture medium without $\mathrm{As}_{2} \mathrm{O}_{3}$ served as the control. Following treatment, the medium was aspirated and the cells were rinsed with PBS, $15 \mathrm{ml}$ MTT solution $(5 \mathrm{mg} / \mathrm{ml}$ in PBS) was added to each well. After a 4-h incubation, $100 \mu \mathrm{l}$ dimethyl sulfoxide was added to dissolve the formazan crystal and incubated for another $10 \mathrm{~min}$ at room temperature, the absorbance value was measured at $490 \mathrm{~nm}$ using an Epoch microplate spectrophotometer (BioTek Instruments, Inc., Winooski, VT, USA).

Matrigel tube formation assay. Matrigel tube formation assay was performed to determine the VM capacity of HepG2 cells and the effect of $\mathrm{As}_{2} \mathrm{O}_{3}$ on VM channels. Each well of a 96-well plate was coated with $80 \mu 1$ Matrigel and allowed to solidify at $37^{\circ} \mathrm{C}$ for $30 \mathrm{~min}$. Cells were seeded into the coated wells and incubated in a humidified incubator at $37^{\circ} \mathrm{C}$ with $5 \% \mathrm{CO}_{2}$ for $24 \mathrm{~h}$. The effect of $\mathrm{As}_{2} \mathrm{O}_{3}$ on tube formation was evaluated using varying concentrations of $\mathrm{As}_{2} \mathrm{O}_{3}$ for $24 \mathrm{~h}$ and $2 \mu \mathrm{M}$ $\mathrm{As}_{2} \mathrm{O}_{3}$ for varying durations. Cells in the control group were cultured in complete medium without $\mathrm{As}_{2} \mathrm{O}_{3}$ for $24 \mathrm{~h}$. Finally, cells were imaged using an inverted microscope (Olympus, Tokyo, Japan; magnification, x200) and tube numbers were counted.

Western blot analysis. Following treatment with $\mathrm{As}_{2} \mathrm{O}_{3}$, cells were harvested and lysed using RIPA buffer (Beijing Solarbio Science and Technology Co., Ltd., Beijing, China) containing $1 \%$ phenylmethane sulfonyl fluoride protease inhibitors. Equivalent quantities of proteins were separated by SDS-PAGE using a $4.5 \%$ stacking gel and an $8 \%$ running gel, and the resolved proteins were transferred to polyvinylidene fluoride membranes using the semi-dry transfer system (Bio-Rad Laboratories, Inc., Hercules, CA, USA). The membranes were blocked with $5 \%$ skimmed milk for $2 \mathrm{~h}$ and incubated with primary antibodies overnight at $4^{\circ} \mathrm{C}$. The primary antibodies included: MMP-2 (cat. no. KG22546, 1:500) and MMP-9 (cat. no. KG22551, 1:500) (both from Nanjing KeyGen Biotech Co., 
Ltd., Nanjing, China), VE-cadherin (cat. no. sc-9989, 1:500), Bax (cat. no. sc-6236, 1:500), Bcl-2 (cat. no. sc-783, 1:500) (all from Santa Cruz Biotechnology, Inc.) and GAPDH (cat. no. KC-5G4, 1:1,000; Shanghai Kangcheng Bioengineering Co., Ltd., Shanghai, China). The membranes were then incubated with horseradish peroxidase-conjugated secondary antibodies (cat. no. ZB-2301, 1:3,000; OriGene Technologies, Inc., Beijing, China) for $1 \mathrm{~h}$ at room temperature and the protein bands on the membranes visualized using an ECL detection system (GE Healthcare Life Sciences, Little Chalfont, UK).

Immunohistochemical (IHC) and histochemical double-staining. Tissue sections $(4 \mu \mathrm{m})$ were sliced from the paraffin-embedded tumor samples, and were stained with hematoxylin and eosin according to routine protocols. All slides were dewaxed in xylenes, rinsed in graded ethanol solutions and finally rehydrated in double-distilled water. Endogenous peroxidase activity was blocked with $3 \%$ hydrogen peroxide in methanol at an ambient temperature for $20 \mathrm{~min}$. Antigen retrieval was performed by heating the slides in $0.01 \mathrm{M}$ sodium citrate buffer for $3 \mathrm{~min}$. After blocking with $3 \%$ normal goat serum for $30 \mathrm{~min}$ to reduce non-specific binding, the slides were incubated in a humidified chamber overnight at $4^{\circ} \mathrm{C}$ with the following primary antibodies: CD105 (cat. no. MS-1290, 1:150; Thermo Fisher Scientific, Inc.), MMP-2 (cat. no. KG22546, 1:150), MMP-9 (cat. no. KG22551, 1:150) (both from Nanjing KeyGen Biotech Co., Ltd.), VE-cadherin (cat. no. sc-9989, 1:150; Santa Cruz Biotechnology, Inc.), then incubated with secondary antibodies (cat. no. PV-6000; OriGene Technologies, Inc.) for $20 \mathrm{~min}$ at room temperature. The sections were stained with freshly dispensed 3,3'-diaminobenzidine solution for observation under a microscope followed by rinsing three times in PBS. Following staining with anti-CD105 and visualization under an inverted microscope, sections were re-dyed with Periodic acid-Schiff (Beijing Reagan Biological Technology Co., Ltd., Beijing, China) at $37^{\circ} \mathrm{C}$ for $15 \mathrm{~min}$ in the dark according to the instructions. CD105-positive vessels indicated blood vessels in tissues and $\mathrm{PAS}^{+} / \mathrm{CD} 105^{-}$channels were defined as VM. For VE-cadherin, MMP-2 and MMP-9 staining, the percentage and intensity of positive cells were measured as previously described (34). More than 5 microscopic fields in one section were observed under x200 magnification.

Statistical analysis. Statistical analysis was performed using Graph Pad Prism 5 (GraphPad Inc., San Diego, CA, USA). The differences were analyzed using a non-parametric Mann-Whitney t-test. All experiments were performed in triplicate, data were expressed as means \pm standard deviation. $\mathrm{P}<0.05$ was considered to indicate a statistically significant difference.

\section{Results}

HepG2 cells form typical tubular structures in vitro. HepG2 cells were plated on Matrigel in 96-well plates and $1 \mathrm{~h}$ later changes in cell morphology were observed, including shape changes, elongation and the formation of needle-like structures (Fig. 1A). After 12 h, typical tubular networks emerged that represented VM (Fig. 1B).

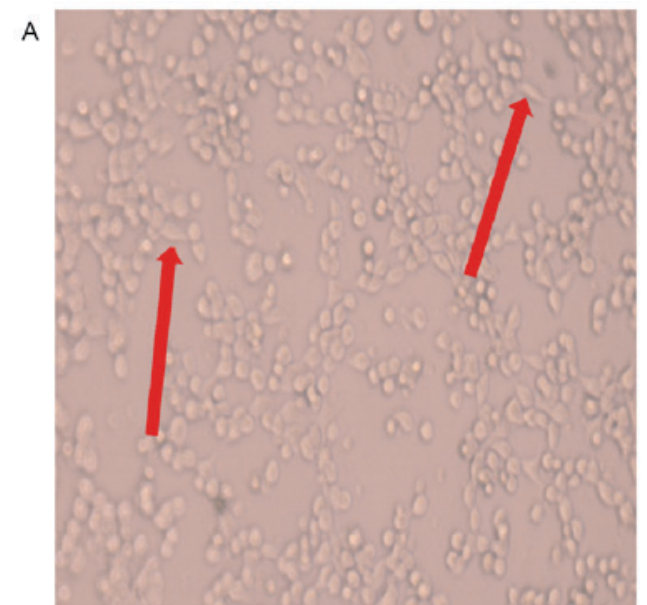

B

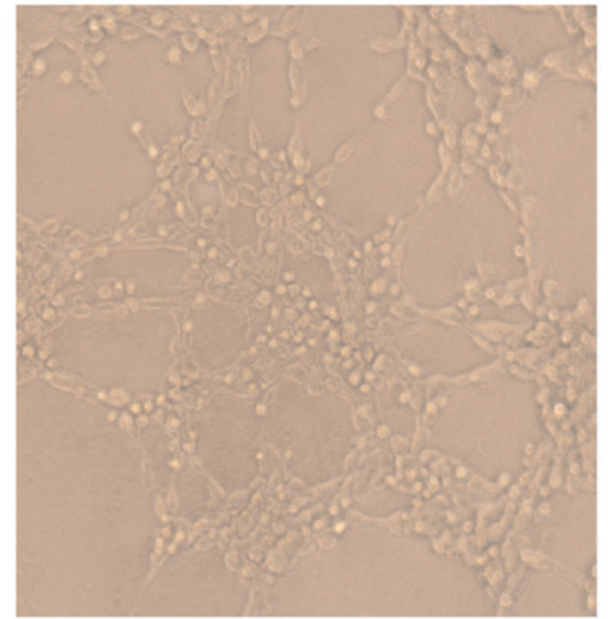

Figure $1 . \mathrm{HepG}_{2}$ cells formed typical tubular structures on Matrigel (magnification, x200). (A) One hour after seeding the cells on Matrigel, cell shape changes, including elongation and the formation of needle-like structures were observed. (B) After $12 \mathrm{~h}$ typical tubular networks emerged.

$\mathrm{As}_{2} \mathrm{O}_{3}$ significantly inhibits the tube formation of Hep $\mathrm{G} 2$ cells prior to cell viability decrease in vitro. In Matrigel tube formation assay, the mean value of tube-like structure numbers in 10 fields under an inverted microscope was obtained, and divided by the optical density (OD) value. The results indicated that $\mathrm{As}_{2} \mathrm{O}_{3}$ induced depolymerization of tube-like structures in a concentration and time-dependent manner. Significant decreases were observed at $2,3,4$ and $5 \mu \mathrm{M}$, respectively $(\mathrm{P}<0.05$; Fig. 2A and $\mathrm{C})$; however, the number of tubes was only moderately reduced at $1 \mu \mathrm{M}$ for $24 \mathrm{~h}$ ( $\mathrm{P}>0.05$; Fig. $2 \mathrm{~A}$ and $\mathrm{C}$ ). When the tubes were exposed to $2 \mu \mathrm{M} \mathrm{As} \mathrm{O}_{3}$ for varying durations, the number of tubes was decreased notably in all groups except the $6 \mathrm{~h}$ group when compared with the control $(\mathrm{P}<0.05$; Fig. $2 \mathrm{~B}$ and $\mathrm{D})$. Furthermore, in the $\mathrm{As}_{2} \mathrm{O}_{3}$ groups, the walls of the tubes became thinner, more fragile and irregular, particularly at concentrations of 4 and $5 \mu \mathrm{M}$ for $24 \mathrm{~h}$. Furthermore, the tubular structures were severely damaged and cells could not form typical structures correctly compared with the remaining groups, whereas in the control group the wall of the tubes became thicker (Fig. 2A). Additionally, the structures diminished gradually with the extension of time at $2 \mu \mathrm{M} \mathrm{As}_{2} \mathrm{O}_{3}$ (Fig. 2B).

Although the viability of cells was reduced by $\mathrm{As}_{2} \mathrm{O}_{3}$, the number of channels was divided by the OD value, hence the 

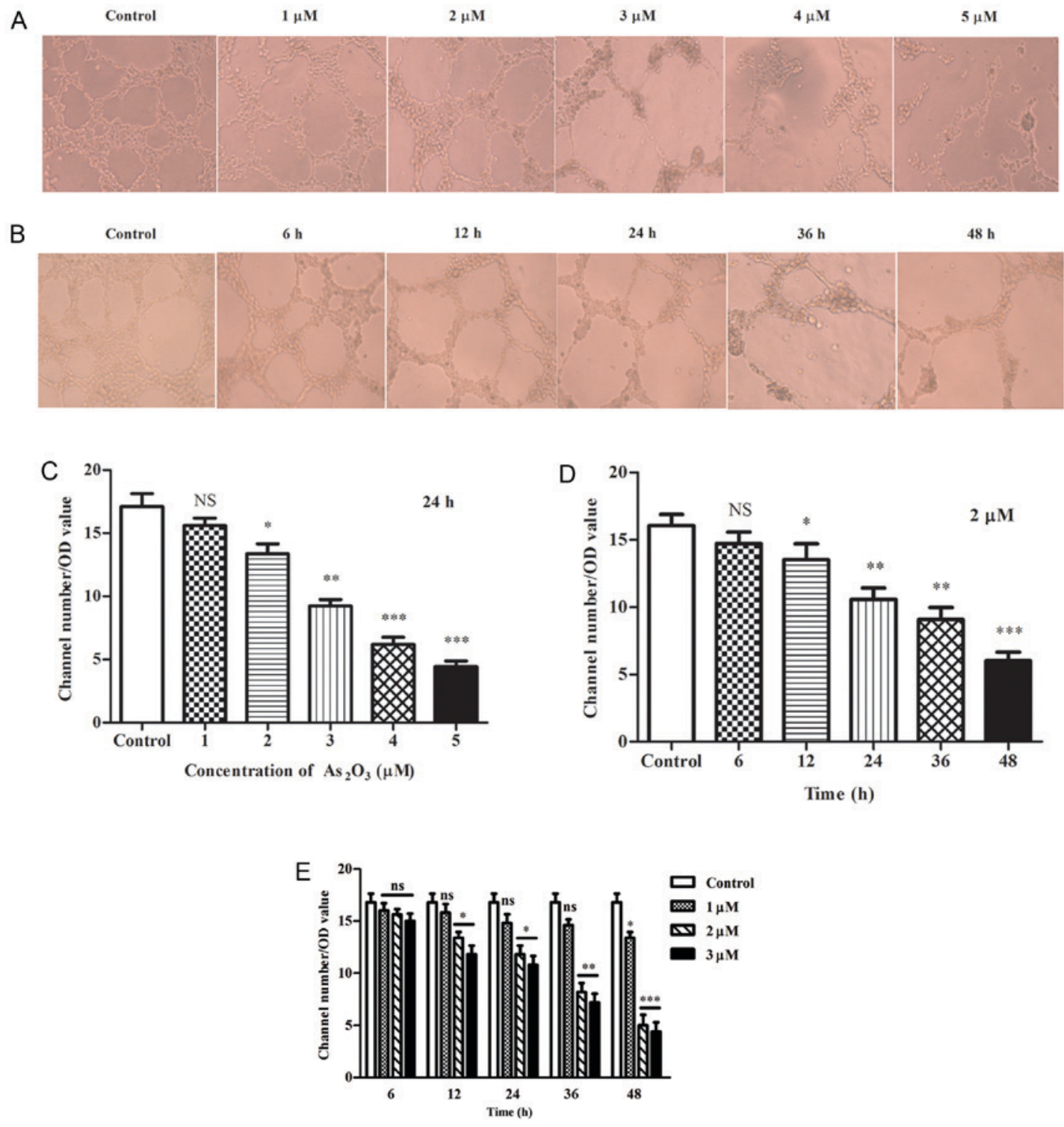

Figure 2. Tubular structure formation of $\mathrm{HepG} 2$ cells is inhibited by $\mathrm{As}_{2} \mathrm{O}_{3}$ in vitro. (A) Different concentrations of $\mathrm{As}_{2} \mathrm{O}_{3}$ were added to the culture suspension for $24 \mathrm{~h}$. (B) $\mathrm{As}_{2} \mathrm{O}_{3}(2 \mu \mathrm{M})$ was added to the culture suspension for varying durations. $\mathrm{As}_{2} \mathrm{O}_{3}$ inhibited tube formation in a (C) concentration- and (D) time-dependent manner. (E) Comparison of channel/OD value in groups exposed to different concentrations of $\mathrm{As}_{2} \mathrm{O}_{3}$ for varying durations. * $\mathrm{P}<0.05$, ${ }^{* *} \mathrm{P}<0.01$ and ${ }^{* * * *} \mathrm{P}<0.001$ vs. control (cells cultured on Matrigel without $\mathrm{As}_{2} \mathrm{O}_{3}$ for $24 \mathrm{~h}$ ). $\mathrm{As}_{2} \mathrm{O}_{3}$, arsenic trioxide; OD, optical density; NS, not statistically significant $(\mathrm{P}>0.05)$.

inhibition of tube structures was not affected by the reduction of total cell numbers. In addition, only when the cells were exposed to 4 and $5 \mu \mathrm{M} \mathrm{As}{ }_{2} \mathrm{O}_{3}$ for $24 \mathrm{~h}$ and $2 \mu \mathrm{M}$ for $>36 \mathrm{~h}$, the cell viability was reduced significantly $(\mathrm{P}<0.05$; Fig. 3$)$, but did not decrease notably with $3 \mu \mathrm{M}$ for $24 \mathrm{~h}$ and $2 \mu \mathrm{M}$ within $24 \mathrm{~h}$. No significant differences were identified when compared with the control group ( $\mathrm{P}>0.05$; Fig. 3 ). Therefore, the inhibition of tube channels was earlier and more obvious than the reduction in cell numbers.

$\mathrm{As}_{2} \mathrm{O}_{3}$ inhibits the VM-associated molecules before apoptosis proteins emerge in vitro. MMP-2 and MMP-9 are two important molecules in ECM remodeling, which are vital in the formation of VM. VE-cadherin is the key molecule in the malignant tumors capable of VM formation and associated with tumor invasion $(35,36)$. The western blot results indicate that the expression levels of MMP-2 and MMP-9
(Fig. 4A), and VE-cadherin (Fig. 4C) decreased significantly and in a concentration-dependent manner when cells were treated with 2, 3, 4 and $5 \mu \mathrm{M} \mathrm{As} \mathrm{O}_{3}$ for $24 \mathrm{~h}(\mathrm{P}<0.05)$. The ratio of $\mathrm{Bax} / \mathrm{Bcl}-2$ was upregulated significantly at 4 and $5 \mu \mathrm{M}$ for $24 \mathrm{~h}(\mathrm{P}<0.05$; Fig. $4 \mathrm{C})$. When cells were exposed to 2 and $3 \mu \mathrm{M} \mathrm{As}_{2} \mathrm{O}_{3}$ for $24 \mathrm{~h}$, the $\mathrm{Bax} / \mathrm{Bcl}-2$ ratio was increased slightly, but no statistical difference was identified when compared with the control group ( $\mathrm{P}>0.05)$. The MMP-9 (Fig. 4B) and VE-cadherin (Fig. 4D) expression levels decreased significantly and in a time-dependent manner when the cells were exposed to $2 \mu \mathrm{M} \mathrm{As} \mathrm{O}_{3}$ for varying durations compared with the control $(\mathrm{P}<0.05)$, and MMP-2 expression levels decreased significantly at 24 and $36 \mathrm{~h}(\mathrm{P}<0.05$; Fig. 4B). However, the ratio of Bax/Bcl-2 was not significantly increased within $24 \mathrm{~h}(\mathrm{P}>0.05)$, although a significant difference was identified when the duration was prolonged to $36 \mathrm{~h}(\mathrm{P}<0.05$; Fig. 4D), which indicated that 

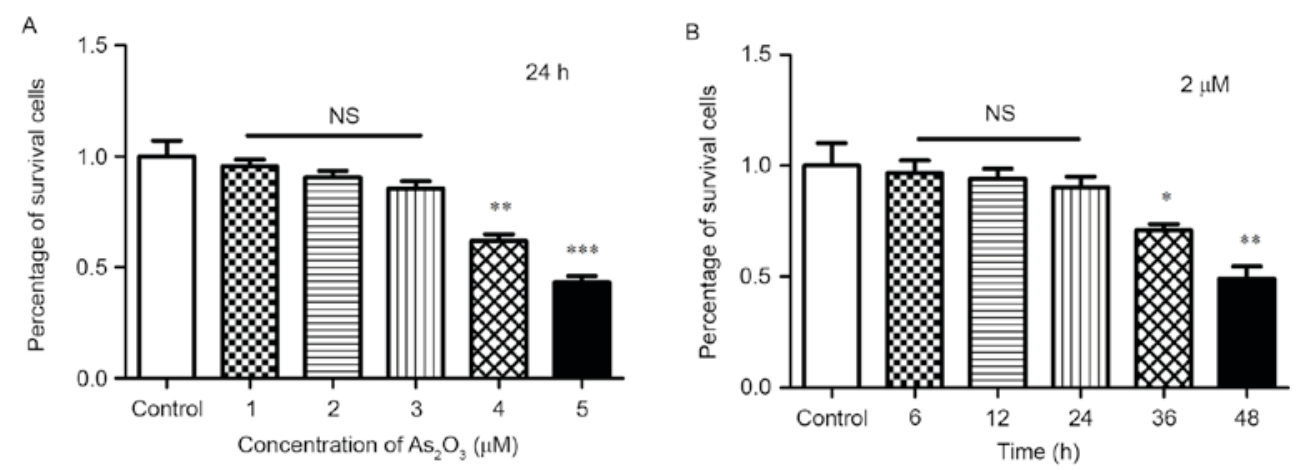

Figure 3. Effect of $\mathrm{As}_{2} \mathrm{O}_{3}$ on cell viability of HepG2 cells was evaluated by methylthiazol tetrazolium assay. (A) HepG2 cells were treated with the indicated concentration of $\mathrm{As}_{2} \mathrm{O}_{3}$ for $24 \mathrm{~h}$. (B) $\mathrm{HepG} 2$ cells were incubated with $2 \mu \mathrm{M} \mathrm{As}_{2} \mathrm{O}_{3}$ for varying durations. ${ }^{*} \mathrm{P}<0.05,{ }^{* *} \mathrm{P}<0.01$ and ${ }^{* * * *} \mathrm{P}<0.001$ vs. control (cells cultured on Matrigel without $\mathrm{As}_{2} \mathrm{O}_{3}$ for $24 \mathrm{~h}$ ). $\mathrm{As}_{2} \mathrm{O}_{3}$, arsenic trioxide; NS, not statistically significant $(\mathrm{P}>0.05)$.
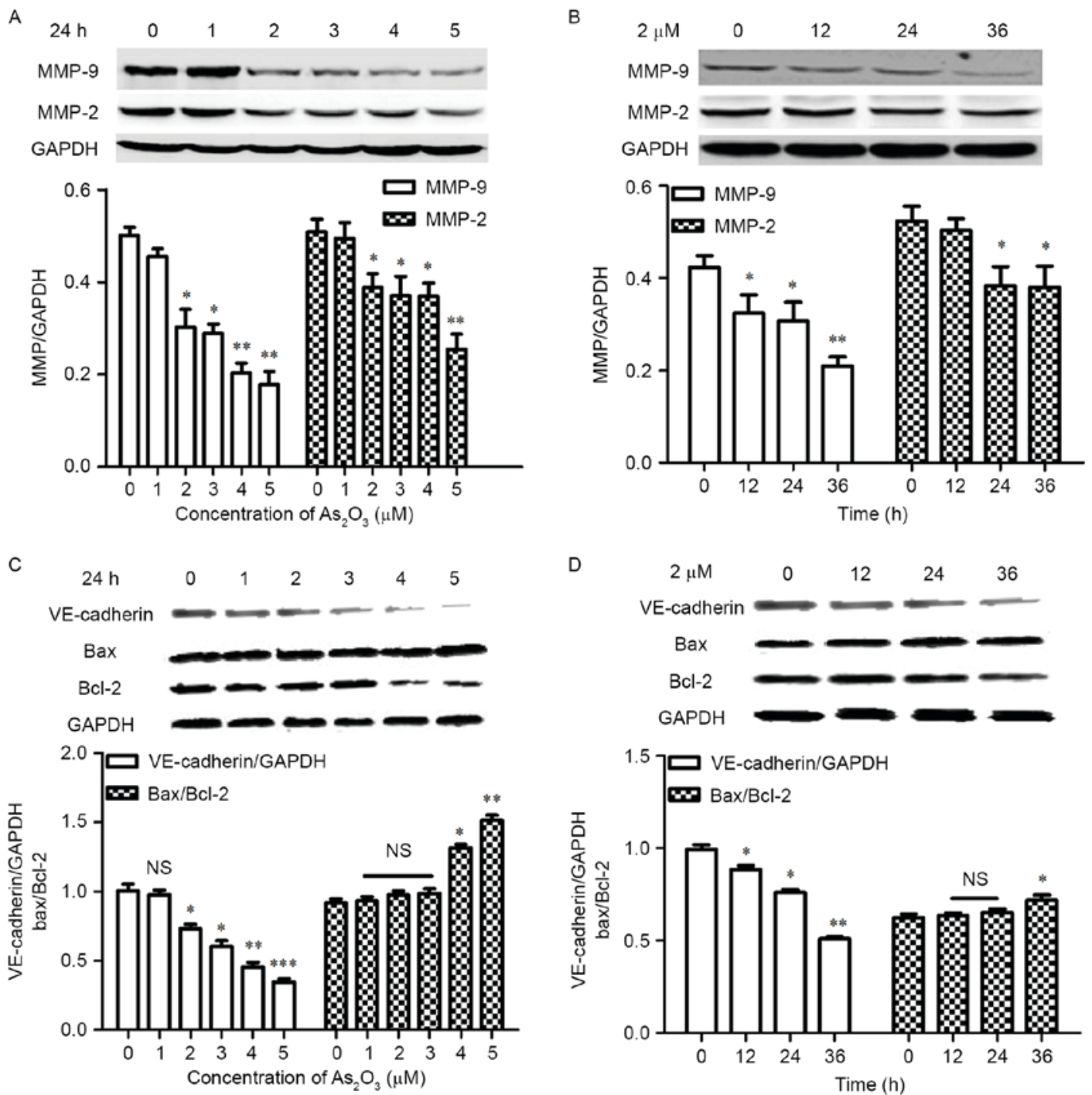

Figure 4. Effect of $\mathrm{As}_{2} \mathrm{O}_{3}$ on VM-associated proteins by western blot analysis. (A) Different concentrations of As $\mathrm{O}_{3}$ for 24-h treatment downregulated the expression levels of MMP-2 and MMP-9 in HepG2 cells. (B) $\mathrm{As}_{2} \mathrm{O}_{3}(2 \mu \mathrm{M})$ inhibits the expression level of MMP-2 and MMP-9 in a time-dependent manner. $\left(\mathrm{C}\right.$ and D) $\mathrm{As}_{2} \mathrm{O}_{3}$ inhibits the expression level of VE-cadherin in a concentration- and time-dependent manner. The ratio of Bax/Bcl-2 was upregulated by $\mathrm{As}_{2} \mathrm{O}_{3}$ at high concentrations and prolonged exposure. GAPDH served as the loading control. ${ }^{*} \mathrm{P}<0.05,{ }^{* *} \mathrm{P}<0.01,{ }^{* * *} \mathrm{P}<0.001$ vs. control. As $\mathrm{O}_{3}$, arsenic trioxide; VM, vasculogenic mimicry; MMP, matrix metalloproteinase; Bax, Bcl-2-associated X protein; Bcl-2, B-cell lymphoma 2; VE, vascular endothelial; NS, not statistically significant $(\mathrm{P}>0.05)$.

the inhibition of VM was associated with the decrease of VM-associated proteins rather than cell apoptosis.
$V M$ structures exist in $H B$ xenografts from mice models, and low-dose $\mathrm{As}_{2} \mathrm{O}_{3}$ inhibits VM channels and VM-associated 
A

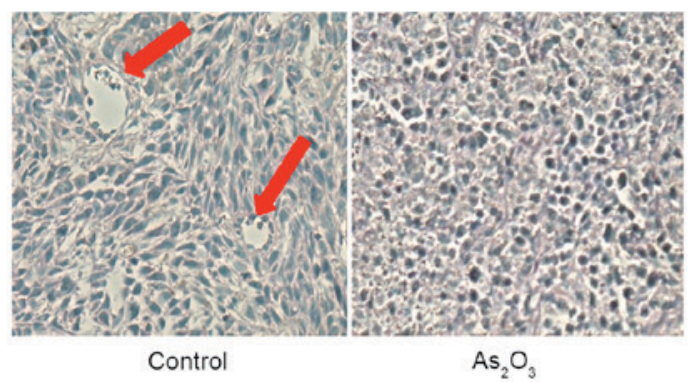

C

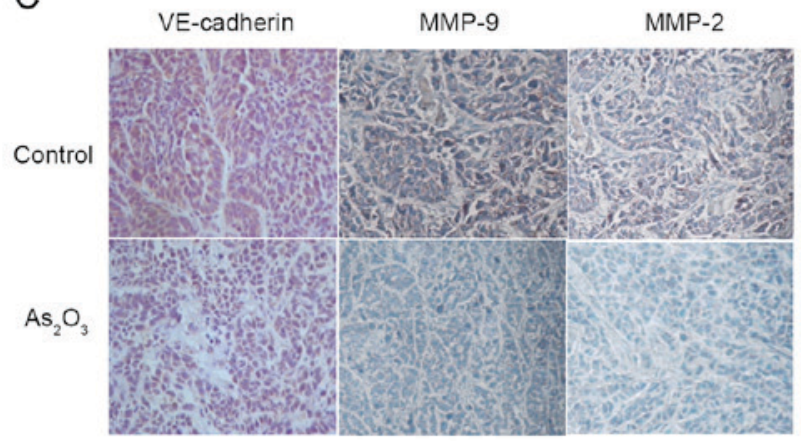

B

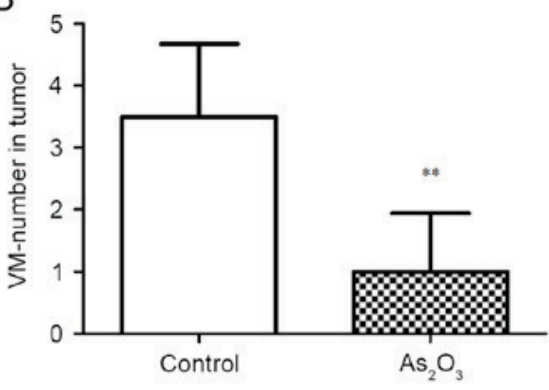

D

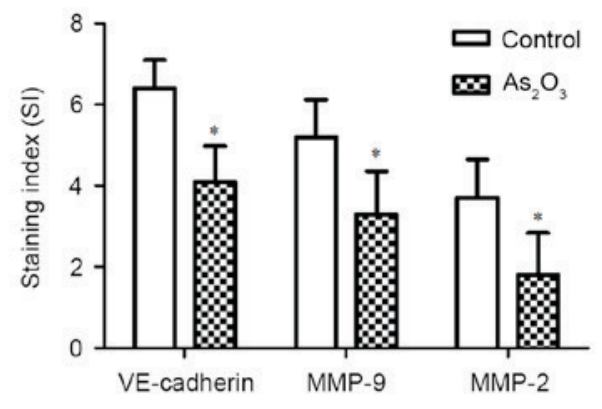

VE-cadherin

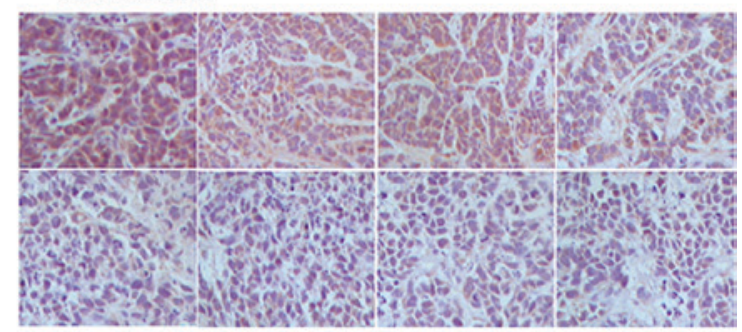

MMP-9

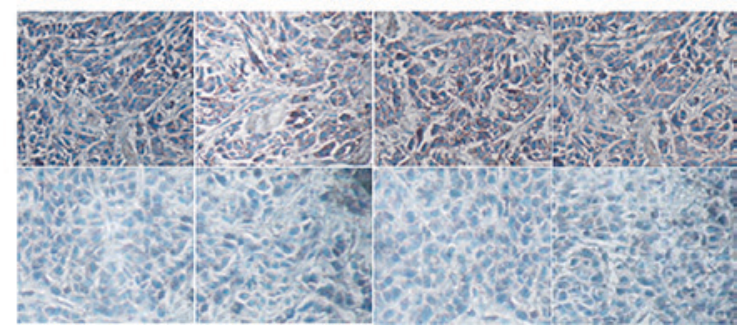

Figure 5. Effect of $\mathrm{As}_{2} \mathrm{O}_{3}$ on VM and VM-associated proteins in vivo (magnification, x200). (A) Evidence of VM in subcutaneous tumor transplants. The channels (red arrow) lined with tumor cells were periodic acid-Schiff ${ }^{+} / \mathrm{CD} 105$. Red blood cells and tumor cells are present in the channel and no hemorrhage or necrotic cells were observed. (B) $\mathrm{As}_{2} \mathrm{O}_{3}\left(2 \mathrm{mg} / \mathrm{kg}\right.$ ) significantly decreased the number of VM structures. (C) $\mathrm{As}_{2} \mathrm{O}_{3}(2 \mathrm{mg} / \mathrm{kg})$ treatment affected the expression level of VM-associated proteins in the xenografts. The staining of VE-cadherin, MMP-2 and -9 in the control group is stronger than that in the $\mathrm{As}_{2} \mathrm{O}_{3}$ group (D) The staining indices of VE-cadherin, MMP-2 and MMP-9 in the $\mathrm{As}_{2} \mathrm{O}_{3}$ group were significantly lower than those in the control. (E) PAS/CD105 and immunohistochemical staining of the remaining four specimens. ${ }^{*} \mathrm{P}<0.05$ and ${ }^{* * *} \mathrm{P}<0.01$ vs. control (specimen from the xenograft of mice who had been administrated with $2 \mathrm{ml}$ PBS peritoneal injection). $\mathrm{As}_{2} \mathrm{O}_{3}$, arsenic trioxide; VM, vasculogenic mimicry; VE, MMP, matrix metalloproteinase; Bax, Bcl-2-associated $\mathrm{X}$ protein; Bcl-2, B-cell lymphoma 2; VE, vascular endothelial; NS, not statistically significant $(\mathrm{P}>0.05)$.

molecules in vivo. In vivo experiments demonstrated that VM structures existed in the HepG2 cell tumor xenografts, which were lined by tumor cells without participation of endothelial cells and surrounded by a $\mathrm{PAS}^{+}$material (stained pink; Fig. 5A; magnification, x200), which was secreted by tumor cells. $\mathrm{PAS}^{+} / \mathrm{CD} 105^{-}$channels were validated by red blood cells and tumor cells in the channel. This was predominantly observed in the marginal zone of the tumor tissues.
In previous studies, high-dose $\mathrm{As}_{2} \mathrm{O}_{3}$ significantly inhibited tumor growth. In the present study, low concentration of $\mathrm{As}_{2} \mathrm{O}_{3}(2 \mathrm{mg} / \mathrm{kg})$ was administrated intraperitoneally to the mice to observe the effect on VM; this dosage is markedly lower than that used in previous studies, which may lead to cell toxicity. An equal quantity of PBS served as the control. The results indicate that the VM structure was observed in all the control specimens (5/5); however, in the $\mathrm{As}_{2} \mathrm{O}_{3}$ group, the 
A
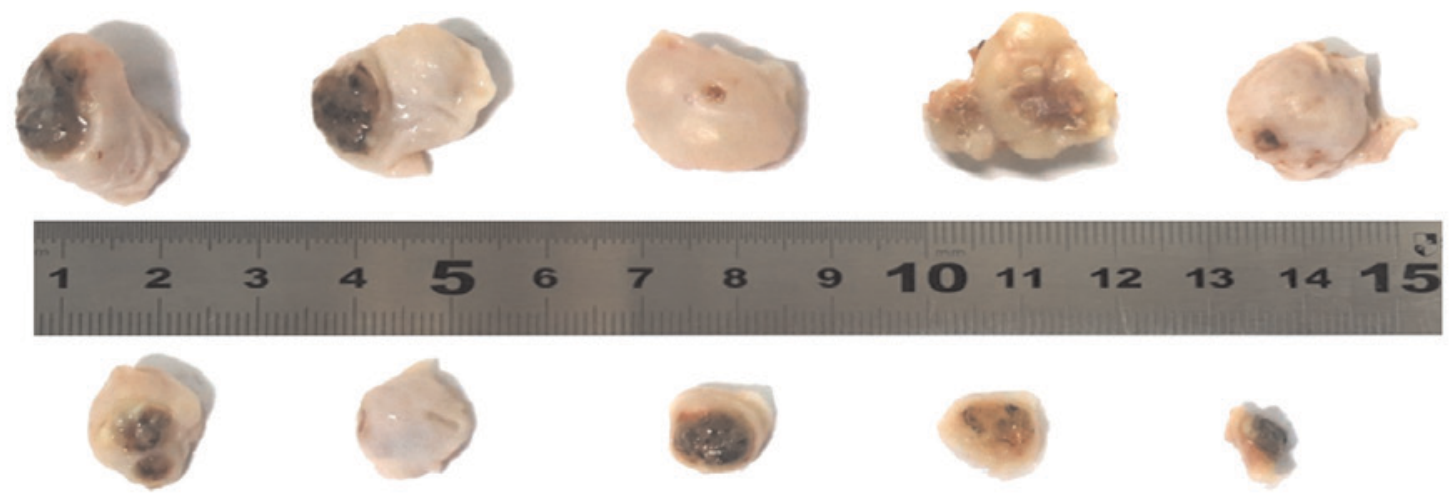

$\mathrm{As}_{2} \mathrm{O}_{3}$

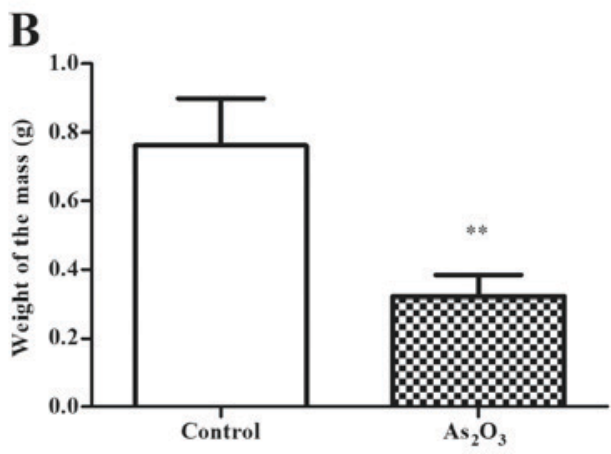

C

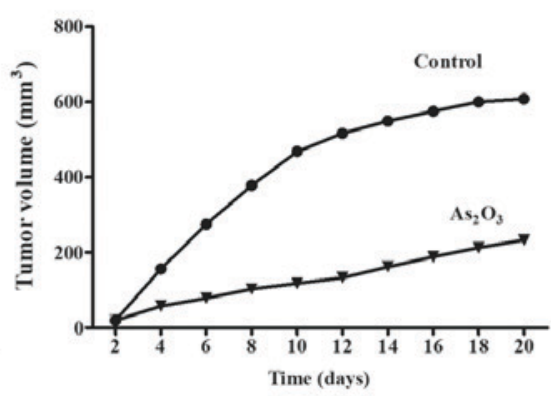

D

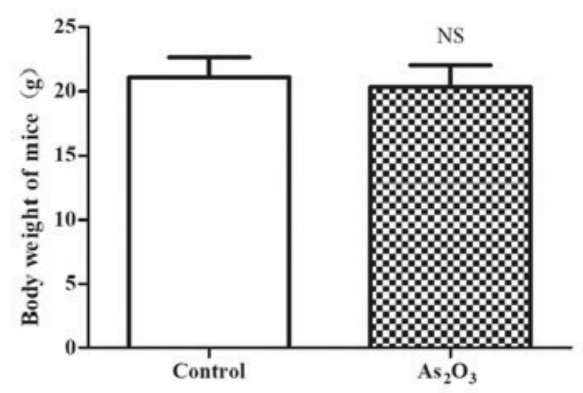

Figure 6. Effect of $\mathrm{As}_{2} \mathrm{O}_{3}$ on the tumor growth of xenografts in vivo. (A) $\mathrm{As}_{2} \mathrm{O}_{3}(2 \mathrm{mg} / \mathrm{kg}$ ) inhibited the growth of HepG2 cell xenografts and the tumor size of the $\mathrm{As}_{2} \mathrm{O}_{3}$ group was smaller than that of the control group. (B) The tumor weights in the $\mathrm{As}_{2} \mathrm{O}_{3}$ and control groups were significantly different. (C) Change of tumor volume over 20 days in the two groups. (D) Comparison of mice body weight in $\mathrm{As}_{2} \mathrm{O}_{3}$ group and control group. ${ }^{* *} \mathrm{P}<0.01$ vs. control. As $\mathrm{O}_{3}$, arsenic trioxide; NS, not statistically significant $(\mathrm{P}>0.05)$.

cells were depressed and could not form channels correctly, and VM structures were only observed in two tissue sections.

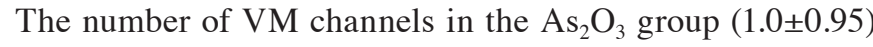
was decreased by $72 \%$ compared with the control group (3.56 \pm 1.81$)$, and a statistically significant difference was observed $(\mathrm{P}<0.01$; Fig. $5 \mathrm{~B})$. No obvious necrotic areas were observed in the visual fields under the microscope.

Additionally, IHC analysis demonstrated that the staining intensity of VM-associated markers in the control group was brown, which was stronger than that of the $\mathrm{As}_{2} \mathrm{O}_{3}$ group, and the percentage of positive cells in the control group was markedly more than that of the $\mathrm{As}_{2} \mathrm{O}_{3}$ group (Fig. 5C). The staining index in the $\mathrm{As}_{2} \mathrm{O}_{3}$ group was significantly lower than that of the control $\left(\mathrm{P}<0.05\right.$; Fig. 5D). These results indicate that $\mathrm{As}_{2} \mathrm{O}_{3}$ inhibits the VM structures by decreasing VM-associated proteins in vivo at a low concentration.

Low-dose $\mathrm{As}_{2} \mathrm{O}_{3}$ inhibits tumor growth in $\mathrm{HB}$ mouse models. In the in vivo study, $2 \mathrm{mg} / \mathrm{kg} \mathrm{As}_{2} \mathrm{O}_{3}$ exhibited significant anti-tumor efficacy on the mouse model of HepG2 cells. The results indicated that the tumors in the $\mathrm{As}_{2} \mathrm{O}_{3}$-treated group were notably smaller than that of the control (Fig. 6A), and the increase of tumor volume in the $\mathrm{As}_{2} \mathrm{O}_{3}$ group was notably slower than that of the control group. The tumor growth curve in the $\mathrm{As}_{2} \mathrm{O}_{3}$ group was smooth, while it was steep in the control group, particularly in the first 10 days (Fig. 6C). Additionally, the weight of tumors in the $\mathrm{As}_{2} \mathrm{O}_{3}$ group was statistically lower than that of the control group $(\mathrm{P}<0.01$; Fig. $6 \mathrm{~B})$. This may be attributed to the inhibition of VM, which is the main blood supply of the tumor during the early stage of tumorigenesis. In addition, the loss of body weight in the $\mathrm{As}_{2} \mathrm{O}_{3}$ group was not significant $(\mathrm{P}>0.05)$ and no other severe adverse effects were observed in the nude mice treated with $\mathrm{As}_{2} \mathrm{O}_{3}$.

\section{Discussion}

$\mathrm{HB}$ is the most common type of pediatric liver malignancy, typically affecting children aged $<5$ years. HB are divided into two histological subtypes based on the level of cell differentiation (37), including epithelial and mixed epithelial mesenchymal. The majority of HB is epithelial, consisting of embryonal and fetal cells, such as HepG2 cells. HB is a tumor characterized by hypervascularity (38) and the incidence of HB has increased in the past 30 years (39). The overall survival of this disease remains poor and, due to its rarity, there is little experience of treating HB. Therefore, there is an urgent requirement to establish an effective treatment strategy for $\mathrm{HB}$.

VM is associated with high tumor grade, invasion, metastasis and short survival, and is a marker of poor clinical prognosis in adult liver cancer, such as hepatocellular carcinoma $(34,40)$. In the present study, the epithelial HB cell line HepG2 cells $(41,42)$ were found to form the typical structure of VM in vivo and in vitro, which may indicate why HB tends to metastasize and relapse.

Formation of VM is a complex process that involves various mechanisms, including EPH receptor A2 (EphA2), cancer stem cells, epithelial-mesenchymal transition, the phosphoinositide 3-kinase signaling pathway, tumor cell plasticity, remodeling of the ECM and microenvironments (such 
as hypoxia). ECM degradation and remodeling are important in the formation of VM channels, a variety of molecular and signaling pathways, including MMPs and VE-cadherin, participate in remodeling of the ECM $(35,36,43,44)$. Among MMPs, MMP-2 and MMP-9 are two important enzymes, which are involved in the remodeling of ECM and are key mediators of invasion, metastasis, tumor angiogenesis and facilitate VM formation $(45,46)$. MMP-2 overexpression may be associated with lymph node metastasis from gastric carcinoma and has been reported to be linked to the recurrence of breast cancer $(47,48)$. VE-cadherin is associated with tumor invasion and is considered to be essential for VM network formation. Plastic tumor cells lacking VE-cadherin are incapable of VM tube formation (36). By contrast, upregulation of VE-cadherin, EphA2, MMP-2 and MMP-9 promotes the formation of VM (49). Therefore, VM-targeting strategies should include these markers to combat the recurrence and metastasis of malignant tumors. Certain experimental evidence indicates that curcumin, thalidomide and gene deletion techniques may successfully inhibit VM and tumor growth. However, the 5-year survival rate of patients with VM remains poor, and there are few effective and feasible methods to treat tumors exhibiting VM.

To the best of our knowledge, this is the first study discussing the effect of $\mathrm{As}_{2} \mathrm{O}_{3}$ on $\mathrm{VM}$ formation. In the present study, a low concentration of $\mathrm{As}_{2} \mathrm{O}_{3}$ was found to inhibit the formation of VM structures in vivo and in vitro, and $\mathrm{As}_{2} \mathrm{O}_{3}$-treated $\mathrm{HepG} 2$ cells exhibited a significantly lower VM capacity than those of the control group. $\mathrm{As}_{2} \mathrm{O}_{3}$ destroys the formation of the tubular structures in vitro at a concentration of $<3 \mu \mathrm{M}$ within $24 \mathrm{~h}$ before cell toxicity appeared, in a time- and concentration-dependent manner. During the in vivo experiments, the VM channels were decreased markedly following treatment with $2 \mathrm{mg} / \mathrm{kg} \mathrm{As}_{2} \mathrm{O}_{3}$, twice a day for a total of 20 days, which was markedly lower than that of clinically tolerable concentrations (50). Additionally, tumor growth was suppressed significantly without obvious adverse reactions.

Furthermore, the expression levels of VE-cadherin, MMP-2 and MMP-9 were decreased significantly with the treatment of low dosage $\mathrm{As}_{2} \mathrm{O}_{3}$ in vivo and in vitro. Previous studies indicated that $\mathrm{As}_{2} \mathrm{O}_{3}$ upregulates the ratio of $\mathrm{Bax} / \mathrm{Bcl}-2$ and induces cell apoptosis $(29,51,52)$; the present in vitro results had the same conclusion, although the ratio of $\mathrm{Bax} / \mathrm{Bcl}-2$ increased significantly only when exposed to higher concentrations and longer exposure of $\mathrm{As}_{2} \mathrm{O}_{3}$ (in cells exposed to 2 and $3 \mu \mathrm{M} \mathrm{As}_{2} \mathrm{O}_{3}$ for $24 \mathrm{~h}$, the ratio of $\mathrm{Bax} / \mathrm{Bcl}-2$ increased only slightly). However, the expression levels of VE-cadherin, MMP-2 and MMP-9 were decreased notably in cells exposed to 2 and $3 \mu \mathrm{M} \mathrm{As} \mathrm{O}_{2} \mathrm{O}_{3}$ for $24 \mathrm{~h}$, which indicated that $\mathrm{As}_{2} \mathrm{O}_{3}$ inhibits tube structures in HepG2 cells via inhibition of VM-associated proteins rather than by inducing cell apoptosis $<3 \mu \mathrm{M}$ within $24 \mathrm{~h}$. IHC results from the in vivo study indicated that the staining intensity of VE-cadherin, MMP-2 and MMP-9 were obviously weaker in the $2 \mathrm{mg} / \mathrm{kg} \mathrm{As}_{2} \mathrm{O}_{3}$ group when compared with that of control group, and no necrotic areas were observed in the tissues. These results indicate that $\mathrm{As}_{2} \mathrm{O}_{3}$ inhibits VE-cadherin, MMP-2 and MMP-9, and thus the formation of VM and tumor growth at low concentrations without cell toxicity.
Complete surgical resection of the tumor is essential for survival of patients with $\mathrm{HB}(53,54)$. HB is a chemotherapy-sensitive tumor and preoperative chemotherapy effectively improves the surgical resectability of the tumor and prolongs the survival time of patients, even in cases of metastasis (55). In previous decades, $\mathrm{As}_{2} \mathrm{O}_{3}$ treatment has exerted therapeutic effects on adult liver malignant tumors and induced attenuation of invasion potential; however, the application of this drug has been limited due to the dose-dependent heart, liver and kidney toxicity (56), therefore the therapeutic window of $\mathrm{As}_{2} \mathrm{O}_{3}$ is particularly narrow. Establishing the appropriate dosage of $\mathrm{As}_{2} \mathrm{O}_{3}$ without significant adverse reactions has become a breakthrough in the treatment of malignant tumors. Furthermore, the drug resistance of HB often occurs after four cycles of chemotherapy (57), therefore avoiding this issue presents a therapeutic challenge.

In conclusion, the present results demonstrate that low-dose $\mathrm{As}_{2} \mathrm{O}_{3}$ is effective in reducing the formation of $\mathrm{VM}$ channels and tumor growth in HB mouse models by inhibiting VM-associated proteins without causing cytotoxicity. Therefore, $\mathrm{As}_{2} \mathrm{O}_{3}$ may present as a promising candidate drug to treat HB by targeting VM.

\section{Acknowledgements}

The present study was supported by the doctoral program of higher education (grant no. 20122307110014).

\section{References}

1. Heck JE, Meyers TJ, Lombardi C, Park AS, Cockburn M, Reynolds P and Ritz B: Case-control study of birth characteristics and the risk of hepatoblastoma. Cancer Epidemiol 37: 390-395, 2013.

2. Stiller CA, Pritchard J and Steliarova-Foucher E: Liver cancer in European children: Incidence and survival, 1978-1997. Report from the Automated Childhood Cancer Information System project. Eur J Cancer 42: 2115-2123, 2006.

3. Czaudernaa P, Haeberle B, Hiyama E, Rangaswami A, Krailo M, Maibach R, Rinaldi E, Feng YR, Aronson D, Malogolowkin M, et al: The Children's Hepatic tumors International Collaboration (CHIC): Novel global rare tumor database yields new prognostic factors in hepatoblastoma and becomes a research model. Eur J Cancer 52: 92-101, 2016.

4. Tanimura M, Matsui I, Abe J, Ikeda H, Kobayashi N, Ohira M, Yokoyama M and Kaneko M: Increased risk of hepatoblastoma among immature children with a lower birth weight. Cancer Res 58: 3032-3035, 1998.

5. Pateva IB, Egler RA and Stearns DS: Hepatoblastoma in an 11-year-old. Case report and a review of the literature. Medicine (Baltimore) 96: e5858, 2017.

6. Park KW, Seo CJ, Yun DY, Kim MK, Kim BS, Han YS, Oh KH and Lee $\mathrm{CH}$ : A case of hepatoblastoma misdiagnosed as combined hepatocellular carcinoma and cholangiocarcinoma in an adult. Clin Mol Hepatol 21: 300-308, 2015.

7. Maniotis AJ, Folberg R, Hess A, Seftor EA, Gardner LM, Pe'er J, Trent JM, Meltzer PS and Hendrix MJ: Vascular channel formation by human melanoma cells in vivo and in vitro: Vasculogenic mimicry. Am J Pathol 155: 739-752, 1999.

8. Zhang S, Guo H, Zhang D, Zhang W, Zhao X, Ren Z and Sun B: Microcirculation patterns in different stages of melanoma growth. Oncol Rep 15: 15-20, 2006.

9. Sood AK, Seftor EA, Fletcher MS, Gardner LM, Heidger PM, Buller RE, Seftor RE and Hendrix MJ: Molecular determinants of ovarian cancer plasticity. Am J Pathol 158: 1279-1288, 2001.

10. Fujimoto A, Onodera H, Mori A, Nagayama S, Yonenaga Y and Tachibana T: Tumour plasticity and extravascular circulation in ECV304 human bladder carcinoma cells. Anticancer Res 26: 59-69, 2006. 
11. Baeten CI, Hillen F, Pauwels P, de Bruine AP and Baeten CG: Prognostic role of vasculogenic mimicry in colorectal cancer Dis Colon Rectum 52: 2028-2035, 2009.

12. Li M, Gu Y, Zhang Z, Zhang S, Zhang D, Saleem AF, Zhao X and Sun B: Vasculogenic mimicry: A new prognostic sign of gastric adenocarcinoma. Pathol Oncol Res 16: 259-266, 2010.

13. Wu S, Yu L, Cheng Z, Song W, Zhou L and Tao Y: Expression of maspin in non-small cell lung cancer and its relationship to vasculogenic mimicry. J Huazhong Univ Sci Technolog Med Sci 32: 346-352, 2012.

14. Van der Schaft DW, Hillen F, Pauwels P, Kirschmann DA, Castermans K, Egbrink MG, Tran MG, Sciot R, Hauben E, Hogendoorn PC, et al: Tumor cell plasticity in Ewing sarcoma, an alternative circulatory system stimulated by hypoxia. Cancer Res 65: 11520-11528, 2005.

15. Vartanian AA, Stepanova EV, Gutorov SL, Solomko ESh, Grigorieva IN, Sokolova IN, Baryshnikov AY and Lichinitser MR: Prognostic significance of periodic acid-Schiff-positive patterns in clear cell renal cell carcinoma. Can J Urol 16: 4726-4732, 2009

16. Francescone R, Scully S, Bentley B, Yan W, Taylor SL, Oh D Moral L and Shao R: Glioblastoma-derived tumor cells induce vasculogenic mimicry through Flk-1 protein activation. J Biol Chem 287: 24821-24831, 2012.

17. Folberg R and Maniotis AJ: Vasculogenic mimicry. APMIS 112 508-525, 2004.

18. Hendrix MJ, Seftor EA, Hess AR and Seftor RE: Vasculogenic mimicry and tumour-cell plasticity: Lessons from melanoma. Nat Rev Cancer 3: 411-421, 2003.

19. Cascone T and Heymach JV: Targeting the angiopoietin/Tie2 pathway: Cutting tumor vessels with a double-edged sword? J Clin Oncol 30: 441-444, 2012.

20. Jain RK, Duda DG, Clark JW and Loeffler JS: Lessons from phase III clinical trials on anti-VEGF therapy for cancer. Nat Clin Pract Oncol 3: 24-40, 2006.

21. Goel S, Duda DG, Xu L, Munn LL, Boucher Y, Fukumura D and Jain RK: Normalization of the vasculature for treatment of cancer and other diseases. Physiol Rev 91: 1071-1121, 2011.

22. Zhang Y, Zhang Z, Li J, Li L, Han X, Han L, Hu L, Wang S, Zhao Y, Li X, et al: Long-term efficacy and safety of arsenic trioxide for first-line treatment of elderly patients with newly diagnosed acute promyelocytic leukemia. Cancer 119: 115-125, 2013.

23. Lallemand Breitenbach V, Guillemin MC, Janin A, Daniel MT, Degos L, Kogan SC, Bishop JM and de Thé H: Retinoic acid and arsenic synergize to eradicate leukemic cells in a mouse model of acute promyelocytic leukemia. J Exp Med 189: 1043-1052, 1999.

24. Pettersson HM, Pietras A, Munksgaard Persson M, Karlsson J, Johansson L, Shoshan MC and Påhlman S: Arsenic trioxide is highly cytotoxic to small cell lung carcinoma cells. Mol Cancer Ther 8: 160-170, 2009.

25. Yu J, Qian HL, Li Y, Wang Y, Zhang X, Liang X, Fu M and Lin C: Arsenic trioxide $\left(\mathrm{As}_{2} \mathrm{O}_{3}\right)$ reduces the invasive and metastatic properties of cervical cancer cells in vitro and in vivo. Gynecol Oncol 106: 400-406, 2007.

26. Du J, Zhou N, Liu H, Jiang F, Wang Y, Hu C, Qi H, Zhong C, Wang $\mathrm{X}$ and $\mathrm{Li} \mathrm{Z}$ : Arsenic induces functional re-expression of estrogen receptor $\alpha$ by demethylation of DNA in estrogen receptor-negative human breast cancer. PLoS One 7: e35957, 2012.

27. Munshi NC, Tricot G, Desikan R, Badros A, Zangari M, Toor A, Morris C, Anaissie E and Barlogie B: Clinical activity of arsenic trioxide for the treatment of multiple myeloma. Leukemia 16 : 1835-1837, 2002

28. Ma ZB, Xu HY, Jiang M, Yang YL, Liu LX and Li YH: Arsenic trioxide induces apoptosis of human gastrointestinal cancer cells. World J Gastroenterol 20: 5505-5510, 2014.

29. Alarifi S, Ali D, Alkahtani S, Siddiqui MA and Ali BA: Arsenic trioxide-mediated oxidative stress and genotoxicity in human hepatocellular carcinoma cells. Onco Targets Ther 6: 75-84, 2013.

30. Lee JC, Lee HY, Moon CH, Lee SJ, Lee WH, Cha HJ, Park SC, Lee YH, Park HJ, Song HT and Min YJ: Arsenic trioxide as a vascular disrupting agent: Synergistic effect with irinotecan on tumor growth delay in a CT26 allograft model. Transl Oncol 6 : 83-91, 2013.

31. Xiao YF, Wu DD, Liu SX, Chen X and Ren LF: Effect of arsenic trioxide on vascular endothelial cell proliferation and expression of vascular endothelial growth factor receptors Flt-1 and KDR in gastric cancer in nude mice. World J Gastroenterol 13: 6498-6505, 2007.
32. Thomas-Schoemann A, Batteux F, Mongaret C, Nicco C, Chéreau C, Annereau M, Dauphin A, Goldwasser F, Weill B, Lemare $\mathrm{F}$ and Alexandre $\mathrm{J}$ : Arsenic trioxide exerts antitumor activity through regulatory $\mathrm{T}$ cell depletion mediated by oxidative stress in a murine model of colon cancer. J Immunol 189 5171-5177, 2012.

33. Verma RJ, Vasu A and Sayyed AA: Arsenic toxicity in mice and its possible amelioration. J Environ Sci (China) 16: 447-453, 2004.

34. Sun B, Zhang S, Zhang D, Du J, Guo H, Zhao X, Zhang W and Hao X: Vasculogenic mimicry is associated with high tumor grade, invasion and metastasis, and short survival in patients with hepatocellular carcinoma. Oncol Rep 16: 693-698, 2006.

35. Zhao N, Sun H, Sun B, Zhu D, Zhao X, Wang Y, Gu Q, Dong X, Liu F, Zhang Y and Li X: miR-27a-3p suppresses tumor metastasis and VM by down-regulating VE-cadherin expression and inhibiting EMT: An essential role for Twist-1 in HCC. Sci Rep 6: 23091, 2016.

36. Hendrix MJ, Seftor EA, Meltzer PS, Gardner LM, Hess AR, Kirschmann DA, Schatteman GC and Seftor RE: Expression and functional significance of VE-cadherin in aggressive human melanoma cells: Role in vasculogenic mimicry. Proc Natl Acad Sci USA 98: 8018-8023, 2001.

37. Bell D, Ranganathan S, Tao J and Monga SP: Novel advances in understanding of molecular pathogenesis of hepatoblastoma: A Wnt/ß-catenin perspective. Gene Expr 17: 141-154, 2017.

38. Dong R, Liu GB, Liu BH, Chen G, Li K, Zheng S and Dong KR: Targeting long non-coding RNA-TUG1 inhibits tumor growth and angiogenesis in hepatoblastoma. Cell Death Dis 7: e2278, 2016.

39. Czauderna P, Lopez-Terrada D, Hiyama E, Häberle B, Malogolowkin MH and Meyers RL: Hepatoblastoma state of the art: Pathology, genetics, risk stratifcation, and chemotherapy. Curr Opini Pediatr 26: 19-28, 2014.

40. Sun T, Zhao N, Zhao XL, Gu Q, Zhang SW, Che N, Wang XH, Du J, Liu YX and Sun BC: Expression and functional significance of Twist1 in hepatocellular carcinoma: Its role in vasculogenic mimicry. Hepatology 51: 545-556, 2010.

41. López-Terrada D, Cheung SW, Finegold MJ and Knowles BB: HepG2 is a hepatoblastoma-derived cell line. Hum Pathol 40: $1512-1515,2009$

42. Xia Z, Zhang N and Ding DK: Proliferation and migration of hepatoblastoma cells are mediated by IRS-4 via PI3K/Akt pathways. Int J Clin Exp Med 7: 3763-3769, 2014.

43. Sood AK, Fletcher MS, Coffin JE, Yang M, Seftor EA, Gruman LM, Gershenson DM and Hendrix MJ: Functional role of matrix metalloproteinases in ovarian tumor cell plasticity. Am J Obstet Gynecol 190: 899-909, 2004

44. Zhang S, Zhang D and Sun B: Vasculogenic mimicry: Current status and future prospects. Cancer Lett 254: 157-164, 2007.

45. Chang $\mathrm{C}$ and Werb Z: The many faces of metalloproteases: Cell growth, invasion, angiogenesis and metastasis. Trends Cell Biol 11: S37-S43, 2001.

46. Chen LX, He YJ, Zhao SZ, Wu JG, Wang JT and Zhu LM: Inhibition of tumor growth and vasculogenic mimicry by curcumin through downregulation of the EphA2/PI3K/MMP pathway in a murine choroidal melanoma model. Cancer Biol Ther 11: 229-235, 2011.

47. Jinga DC, Blidaru A, Condrea I, Ardeleanu C, Dragomir C, Szegli G, Stefanescu M and Matache C: MMP-9 and MMP-2 gelatinases and TIMP-1 and TIMP-2 inhibitors in breast cancer: Correlations with prognostic factors. J Cell Mol Med 10: 499-510, 2006.

48. Mönig SP, Baldus SE, Hennecken JK, Spiecker DB, Grass G, Schneider PM, Thiele J, Dienes HP and Hölscher AH Expression of MMP-2 is associated with progression and lymph node metastasis of gastric carcinoma. Histopathology 39: 597-602, 2001.

49. Kirschmann DA, Seftor EA, Hardy KM, Seftor RE and Hendrix MJ: Molecular pathways: Vasculogenic mimicry in tumor cells: Diagnostic and therapeutic implications. Clin Cancer Res 18: 2726-2732, 2012

50. Øra I, Bondesson L, Jönsson C, Ljungberg J, Pörn-Ares I, Garwicz S and Pâhlman S: Arsenic trioxide inhibits neuroblastoma growth in vivo and promotes apoptotic cell death in vitro. Biochem Biophys Res Commun 277: 179-185, 2000.

51. Siu KP, Chana JY and Fung KP: Effect of arsenic trioxide on human hepatocellular carcinoma HepG2 cells: Inhibition of proliferation and induction of apoptosis. Life Sci 71: 275-285, 2002 . 
52. Wang Y, Bai C, Guan H, Chen R, Wang X, Wang B, Jin H and Piao F: Subchronic exposure to arsenic induces apoptosis in the hippocampus of the mouse brains through the $\mathrm{Bcl}-2 / \mathrm{Bax}$ pathway. J Occup Health 57: 212-221, 2015.

53. Venkatramani R, Furman WL, Fuchs J, Warmann SW and Malogolowkin MH: Current and future management strategies for relapsed or progressive hepatoblastoma. Paediatr Drugs 14: 221-232, 2012

54. von Schweinitz D: Management of liver tumors in childhood. Semin Pediatr Surg 15: 17-24, 2006.

55. Zheng MH, Zhang L, Gu DN, Shi HQ, Zeng QQ and Chen YP Hepatoblastoma in adult: Review of the literature. J Clin Med Res 1: 13-16, 2009.
56. Miller WH Jr, Schipper HM, Lee JS, Singer J and Waxman S: Mechanisms of action of arsenic trioxide. Cancer Res 62: 3893-3903, 2002.

57. Von Schweinitz D, Hecker H, Schmidt-von-Arndt G and Harms D: Prognostic factors and staging systems in childhood hepatoblastoma. Int J Cancer 74: 593-599, 1997.

(7) (9) This work is licensed under a Creative Commons Attribution 4.0 International (CC BY-NC 4.0) License 